Research paper

\title{
Natural regeneration in Siberian fir (Abies sibirica Ledeb.) forests subjected to invasion of the four-eyed fir bark beetle (Polygraphus proximus Blandf.)
}

\author{
Nikita Debkov
}

Debkov, N. 2019. Natural regeneration in Siberian fir (Abies sibirica Ledeb.) forests subjected to invasion of the four-eyed fir bark beetle (Polygraphus proximus Blandf.). - Forestry Studies | Metsanduslikud Uurimused 70, 44-57, ISSN 1406-9954. Journal homepage: http:/ / mi.emu. ee/forestry.studies

\begin{abstract}
This study assessed the potential of natural regeneration (NR) of forests in Western Siberia, dominated by Siberian fir (Abies sibirica Ledeb.) and damaged due to the invasion of the four-eyed fir bark beetle (Polygraphus proximus Blandf.). The leading methods for investigating this problem are the sample plot method and the transect method, which allow revealing the features of NR, their morphological structure and spatial distribution. Analysis of the occurrence and structure of NR revealed a correlation between the degree of stand damage and sapling state. The spatial structure was highly heterogeneous, testifying the group location of NR and the variable density. For $63 \%$ of the sample plots, a decrease in saplings was recorded as a result of the impact of the four-eysouthern ed fir bark beetle. Most of the dead saplings were large (95\%), and dead saplings accounted for 10-50\%. A positive correlation was found between the decrease in saplings and the state of the fir forest. The number of saplings varied from 1,233 to 19,200 plants ha-1 ${ }^{-1}$ with fir being the dominant species. Fir forests of Western Siberia, damaged by the four-eyed fir bark beetle, have the potential for regeneration.
\end{abstract}

Key words: microsites, invaders, forest degradation.

Author's address: Laboratory of Monitoring of Forest Ecosystems, Institute of Monitoring of Climatic and Ecological Systems, Siberian Branch of the Russian Academy of Sciences, Academichesky ave.10/3,634055 Tomsk, Russia; e-mail: nikitadebkov@yandex.ru

\section{Introduction}

Since the beginning of the $21^{\text {st }}$ century, the degradation of coniferous evergreen forests in the boreal zone has intensified across the globe (Aitken et al., 2008; Allen et al., 2010; Worrall et al., 2010; Yousefpour et al., 2010; Martinez-Vilalta et al., 2012; Anderegg et al., 2013), mainly as a result of root rot and bacteria (Raffa et al., 2008), insect pests (Logan et al., 2003), and increasing aridity (Kharuk et al., 2013). Irrespective of the main cause of this large-scale dieback, the synergism of these factors entails the weakening of stands and the sensitisation of trees to various impacts, in particular insect pests, which are often the final factor leading to the death of coniferous forests.

An increasing number of invasive organisms (mainly insects) in forest ecosystems contributes to this problem, which leads to a change in the structure of biological diver- 
sity (Kenis et al., 2009; Straw et al., 2013) and, in extreme cases, even to its loss (Born et al., 2005; Poland \& McCullough, 2006).

In South Siberia, against the backdrop of these global processes, a phenomenon unique to the Siberian taiga is currently being observed: the large-scale dieback of Siberian fir (Abies sibirica Ledeb.) as a result of invasion and mass reproduction of the native Far Eastern bark beetle, Polygraphus proximus Blandf. (Krivets et al., 2015). At first, after the beginning of mass reproduction of the Far Eastern invader in fir forests of Siberia, predictions of the possibility of complete loss not only of the forest-forming role of Siberian fir, but also of its biological status, were frequently voiced. Despite these forecasts, until recently, little attention has been paid to the regenerative functions of the ecosystems disturbed by the four-eyed fir bark beetle.

In this regard, the aim of the research was to assess the regeneration potential of fir ecosystems and to predict their succession dynamics in the West Siberian region in the context of four-eyed fir bark beetle invasion.

\section{Material and Methods}

Studies were conducted in the Tomsk region on 22 sample plots (SPs), established in 2012-2017 by the Institute for Monitoring of Climatic and Ecological Systems (SB RAS), both in pure fir stands (with a share of other species up to $20 \%$ ) and in mixed stands with Siberian pine (Pinus sibirica Du Tour), Siberian spruce (Picea obovata Ledeb.), silver birch (Betula pendula Roth.), and aspen (Populus tremula L.). The examined stands were premature and mature-aged and showed varying degrees of damage - from weakened (average stand health category 1.6-2.5 points) to severely weakened (2.6-3.5 points) and degraded (3.6 points or higher).

Natural regeneration (NR) studies were performed according to methodological instructions (Pobedinsky, 1966), modified in accordance with the tasks assigned. Depending on the characteristics of the communities studied (site area, quantitative parameters and NR height), the calculation was carried out in continuous transects with 25 square counting plots of $4 \mathrm{~m}^{2}$ or on intermittent transects in 30 circular plots of $10 \mathrm{~m}^{2}$.

We determined the parameters composition, height, diameter, age, number, length and projection of the crown, linear growth of the axial shoot and lateral shoot of the I order. Also, model specimens of saplings were collected (three plants per height group) to determine the morphological characteristics and age.

The location of NR sites was estimated with the calculation of occurrence (the ratio of registration sites with at least one sample of sapling the total number of SP). To determine the spatial distribution of saplings, the scattering index proposed by R.A. Fisher was calculated (Svalov, 1985). The main parameters adopted in the work to categorise viable saplings (Uspensky, 1987) are the ratio of the current linear growth of the axial shoot and the lateral shoot of the first order, the so-called "ecological coefficient of the crown" (more than 0.5 for small saplings, 0.7 for medium saplings and 1 for large saplings), the length of the crown compared to the trunk (more than $61 \%$ ), and the ratio of crown length to width (more than 0.9 ). The values of the ecological coefficient of the crown adopted in this paper differ from those generally accepted in Russian forest science in relation with the features of Siberian fir ontogenesis (Makhatkov, 1991). In the early and late immature ontogenetic states, applicable to the small and medium fir saplings, respectively, the growth of the lateral branches exceeding the axial shoot is characteristic.

The structural organisation of microsites in forest communities has been studied and expressed in the formation of a specific microrelief in the life and death of trees (Zaugolnova \& Braslavskaya, 2010). 
This classification was substantially modified by the author of the present study for specific research conditions. Accordingly, micro-habitats (microsites) of the first order were identified as undercrown plots of living and dead trees (with a division into dieback, windbreak and windfall) as well as intercrown plots. Within each micro-habitat of the first order, second-order micro-habitats were further singled out: even plots, pans and deadwood locations - stumps and deadwood.

Statistical analysis was performed via descriptive statistics (value \pm standard error) in the program Statistica 10. To assess significant differences between the two independent variables, the nonparametric
Mann-Whitney U test was used; to determine the relationship between the indices, the Spearman correlation was applied.

\section{Results}

The distribution of the four-eyed fir bark beetle in the Tomsk region

As of 2014 (Krivets \& Baranchikov, 2015), the invader was noted in six districts of the Tomsk region (Figure 1): Bakcharsky (3), the southern part of Verkhneketsky (4), Krivosheinsky (9), southern part of Pervomaisky (12), Teguldetsky (13) and Tomsky (14).

\section{Legend:}

invader occurrence as of 2018;

(1) numbers of administrative districts of the Tomsk region (explanations in the text); sample plots.

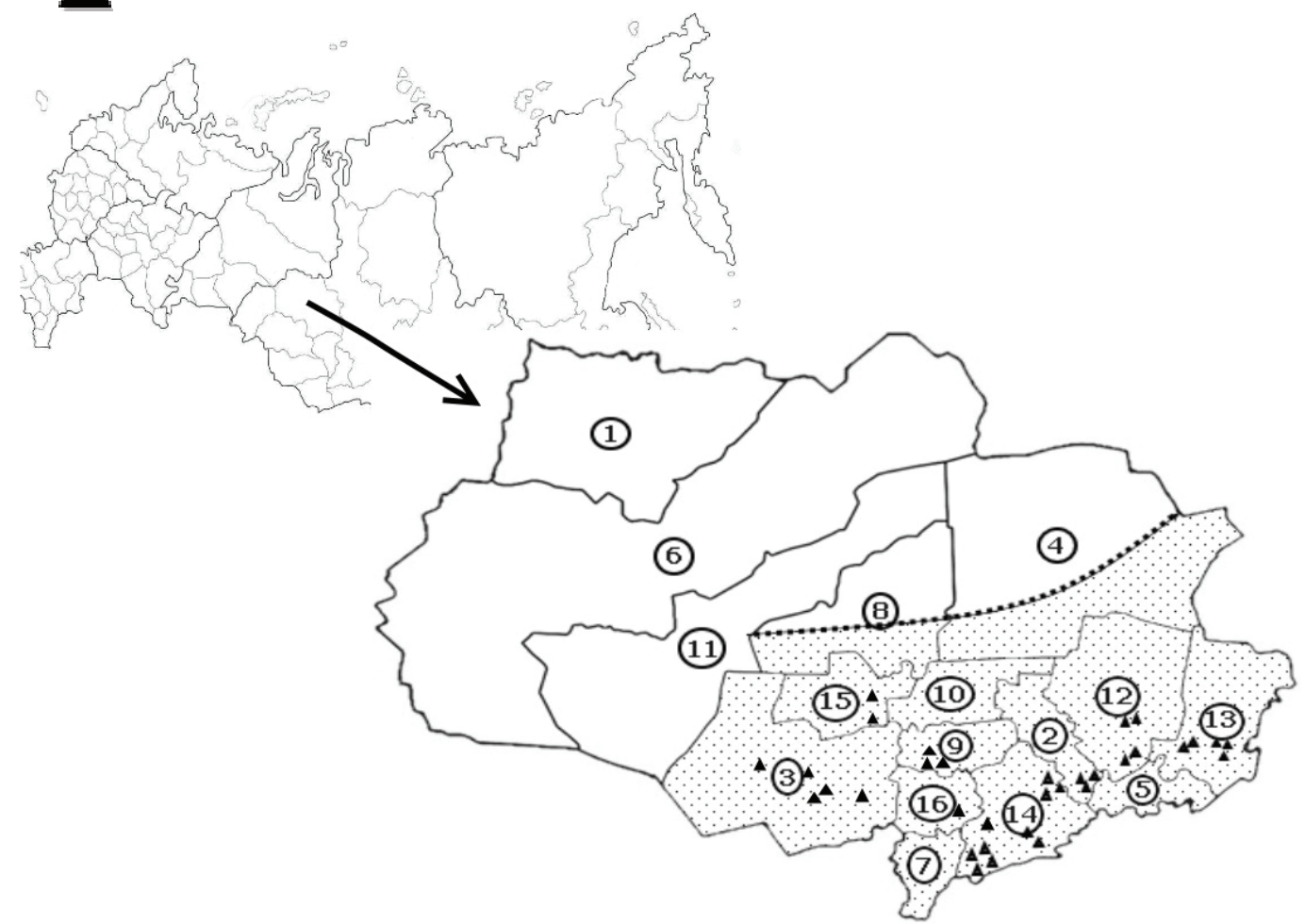

Figure 1. The modern distribution of the four-eyed fir bark beetle in the Tomsk region and the location of sample plots. 
In 2018, as a result of field studies conducted by the SB RAS, material of the Department of Forestry of the Tomsk region and a survey conducted by foresters, the presence of the four-eyed fir bark beetle in seven new districts of the region was reliably established, namely: Asinovsky (2), Zyryansky (5), Kozhevnikovsky (7), Kolpashevsky (8), Molchanovsky (10), Chainsky (15) and Shegarsky (16) administrative districts and in the northern part of the Pervomaisky district. In the northern part of the Tomsk region, which includes Alexandrovsky (1), the northern part of Verkhneketsky (4), Kargasoksky (6) and Parabelsky districts (11), the invader has not yet been recorded.

Sample plots were established in nine administrative districts of the Tomsk region within the southern taiga, both in harvested forests and in forests of different categories of protection (green zones, natural reserves, water protection zones). Of the sampled stands, $29 \%$ were weak, $25 \%$ were severely weakened and $46 \%$ were degraded. The primary areas of invasion are the districts Tomsky (14) and Teguldetsky (13), located on the right bank of the Ob River. When assessing the state of the stands in the primary and secondary invasion areas, no significant differences were found (Mann-Whitney test, $p=0.63$ ), which leads us to infer that the invader explores and infests almost the entire forage base and further sharply reduces the activity. More viable stands are weakened in one way or another, and the less viable stands quickly degrade. The length of the period during which the four-eyed fir bark beetle stays in a particular area plays only a minor role, without differences between areas of primary and secondary distribution.

\section{Morphological features of the saplings}

The species composition of NR in the fir forests of the right bank of the $\mathrm{Ob}$ River was characterised by the predominance
(89-100\%) of Siberian fir (Table 1). As accompanying species, Siberian spruce (1$9 \%)$ and Siberian pine were most frequently found (1-4\%). Based on morphological parameters characterising the state of the assimilative apparatus (crown) of the saplings, the viability of NR can be concluded.

The species composition of NR sites in fir forests on the left bank of the Ob River was also characterised by the predominance $(81-98 \%)$ of Siberian fir (Table 2). Siberian spruce $(1-19 \%)$, Siberian pine $(2-$ $7 \%)$ and aspen (1-9\%) were most frequently found as accompanying species. Morphologically the saplings were healthy, although viability was lower than on the right bank of the Ob River.

Comparative analysis of the NR structure shows that fir forests on the left bank of the $\mathrm{Ob}$ River have a slightly lower proportion of fir in the composition, mainly due to the presence of aspen. Small saplings are characterised by a significantly lower amplitude of most morphological parameters, but the average values are comparable. This generally applies to the medium saplings, yet a somewhat smaller age and higher linear growth was noted, i.e. conditions for development are more favourable on the right bank of the $\mathrm{Ob}$ River. A significantly lower participation of large saplings in under-canopy regeneration on the left bank should be noted. At the same time, despite the approximately equal age, the height and parameters of the crown were significantly higher in large saplings on the right bank. In general, the average height of NR saplings on the left bank was $63 \pm 10$ $\mathrm{cm}$ (limited to 19-100 cm) compared to 116 $\pm 25 \mathrm{~cm}$ (limited to $21-305 \mathrm{~cm}$ ) on the right bank, although this difference was not significant (Mann-Whitney test, $p=0.13$ ).

\section{The spatial structure of NR}

The average occurrence coefficient was similar for the two sites (Figure 2). On the right bank, it was equal to $75 \pm 6 \%$ (limited to $36-100 \%)$, while on the left bank, it 
Table 1. Characteristics of saplings in fir forests damaged by the four-eyed fir bark beetle on the right bank of the $0 \mathrm{~b}$ River.

\begin{tabular}{|c|c|c|c|c|c|c|c|c|c|}
\hline No. SP & $\begin{array}{l}\text { Composi- } \\
\text { tion, } \\
\%\end{array}$ & $\begin{array}{l}\text { Size } \\
\text { cate- } \\
\text { gory }\end{array}$ & $\begin{array}{l}\text { Age, } \\
\text { yrs }\end{array}$ & $\begin{array}{l}\text { Height, } \\
\text { cm }\end{array}$ & $\begin{array}{l}\text { Diameter, } \\
\mathrm{cm}\end{array}$ & $\begin{array}{l}\text { Crown } \\
\text { length, } \\
\mathrm{cm}\end{array}$ & $\begin{array}{l}\text { Crown } \\
\text { width, } \\
\mathrm{cm}\end{array}$ & $\begin{array}{c}\text { Growth } \\
\text { of axial } \\
\text { shoot, cm } \\
\text { yrs }^{-1}\end{array}$ & $\begin{array}{c}\text { Growth } \\
\text { of lateral } \\
\text { shoot (I } \\
\text { order), } \\
\text { cm yrs }^{-1}\end{array}$ \\
\hline \multicolumn{10}{|c|}{ Larinsky landscape reserve } \\
\hline \multirow{3}{*}{$1-12$} & \multirow{3}{*}{$89 F 8 S 3 P$} & I & $10 \pm 3$ & $46 \pm 11$ & $0.8 \pm 0.1$ & $30 \pm 11$ & $37 \pm 9$ & $2.3 \pm 0.9$ & $5.0 \pm 0.6$ \\
\hline & & II & $17 \pm 3$ & $109 \pm 10$ & $1.8 \pm 0.2$ & $83 \pm 10$ & $87 \pm 22$ & $10.7 \pm 2.7$ & $10.0 \pm 1.1$ \\
\hline & & III & $33 \pm 7$ & $307 \pm 79$ & $4.6 \pm 1.0$ & $212 \pm 50$ & $198 \pm 42$ & $35.7 \pm 5.8$ & $13.0 \pm 0.6$ \\
\hline \multirow{3}{*}{$2-12$} & \multirow{3}{*}{$94 \mathrm{~F} 6 \mathrm{~S}$} & I & $11 \pm 2$ & $33 \pm 3$ & $0.5 \pm 0.1$ & $22 \pm 1$ & $23 \pm 5$ & $1.7 \pm 0.3$ & $4.7 \pm 0.7$ \\
\hline & & II & $17 \pm 1$ & $98 \pm 14$ & $1.9 \pm 0.3$ & $78 \pm 15$ & $78 \pm 13$ & $3.7 \pm 0.9$ & $6.3 \pm 0.3$ \\
\hline & & III & $27 \pm 4$ & $309 \pm 64$ & $3.7 \pm 0.9$ & $216 \pm 35$ & $127 \pm 22$ & $16.0 \pm 2.9$ & $10.0 \pm 1.1$ \\
\hline \multirow{3}{*}{$3-12$} & \multirow{3}{*}{ 99F1P } & I & $9 \pm 2$ & $31 \pm 2$ & $0.7 \pm 0.1$ & $20 \pm 1$ & $19 \pm 3$ & $3.7 \pm 0.6$ & $6.0 \pm 1.0$ \\
\hline & & II & $18 \pm 1$ & $87 \pm 3$ & $1.7 \pm 0.2$ & $73 \pm 3$ & $69 \pm 4$ & $14.0 \pm 2.5$ & $10.8 \pm 1.3$ \\
\hline & & III & $20 \pm 1$ & $190 \pm 5$ & $3.0 \pm 0.3$ & $173 \pm 10$ & $120 \pm 5$ & $22.0 \pm 3.9$ & $12.0 \pm 1.1$ \\
\hline \multirow{3}{*}{ 4-12 } & \multirow{3}{*}{ 99F1P } & I & $13 \pm 1$ & $43 \pm 6$ & $0.8 \pm 0.1$ & $31 \pm 5$ & $30 \pm 5$ & $5.8 \pm 1.4$ & $7.2 \pm 0.6$ \\
\hline & & II & $21 \pm 2$ & $73 \pm 6$ & $1.2 \pm 0.1$ & $43 \pm 5$ & $51 \pm 3$ & $5.7 \pm 1.4$ & $6.8 \pm 1.3$ \\
\hline & & III & $44 \pm 5$ & $302 \pm 78$ & $4.8 \pm 0.8$ & $189 \pm 49$ & $127 \pm 10$ & $33.0 \pm 4.5$ & $16.3 \pm 0.3$ \\
\hline \multicolumn{10}{|c|}{ Tomsk forest unit } \\
\hline \multirow{3}{*}{$5-12$} & \multirow{3}{*}{$84 F 16 S$} & I & $20 \pm 1$ & $33 \pm 4$ & $0.6 \pm 0.1$ & $20 \pm 3$ & $31 \pm 6$ & $2.5 \pm 0.5$ & $4.3 \pm 0.5$ \\
\hline & & II & $26 \pm 1$ & $98 \pm 8$ & $1.6 \pm 0.1$ & $63 \pm 7$ & $71 \pm 7$ & $7.3 \pm 1.6$ & $7.5 \pm 1.0$ \\
\hline & & III & $29 \pm 1$ & $217 \pm 15$ & $3.6 \pm 0.3$ & $149 \pm 15$ & $150 \pm 9$ & $18.7 \pm 5.2$ & $10.9 \pm 2.0$ \\
\hline \multirow{3}{*}{$30-16$} & \multirow{3}{*}{$87 F 135$} & I & $15 \pm 1$ & $36 \pm 3$ & $0.6 \pm 0.1$ & $16 \pm 2$ & $30 \pm 3$ & $1.3 \pm 0.3$ & $3.2 \pm 0.3$ \\
\hline & & II & $26 \pm 1$ & $87 \pm 6$ & $1.3 \pm 0.1$ & $36 \pm 4$ & $64 \pm 7$ & $3.4 \pm 0.9$ & $4.8 \pm 0.5$ \\
\hline & & III & $37 \pm 1$ & $260 \pm 29$ & $3.2 \pm 0.3$ & $114 \pm 18$ & $167 \pm 16$ & $5.2 \pm 1.4$ & $7.1 \pm 1.7$ \\
\hline \multicolumn{10}{|c|}{ Tomsk urban forests } \\
\hline \multirow{3}{*}{$6-12$} & \multirow{3}{*}{$100 \mathrm{~F}$} & I & - & $12 \pm 1$ & $0.3 \pm 0.1$ & - & - & - & - \\
\hline & & II & - & $60 \pm 7$ & $0.7 \pm 0.1$ & $25 \pm 5$ & $45 \pm 5$ & $1.5 \pm 0.5$ & $3.7 \pm 0.2$ \\
\hline & & III & $28 \pm 3$ & $378 \pm 44$ & $5.1 \pm 0.6$ & $231 \pm 35$ & $180 \pm 12$ & $11.7 \pm 2.3$ & $8.8 \pm 0.7$ \\
\hline \multicolumn{10}{|c|}{ Kornilovskoe forest unit } \\
\hline \multirow{3}{*}{$32-16$} & \multirow{3}{*}{$89 F 9 S 2 P$} & I & $10 \pm 1$ & $39 \pm 3$ & $0.6 \pm 0.1$ & $26 \pm 4$ & $24 \pm 5$ & $2.0 \pm 0.1$ & $2.8 \pm 0.4$ \\
\hline & & II & $21 \pm 2$ & $87 \pm 11$ & $1.5 \pm 0.3$ & $61 \pm 12$ & $58 \pm 10$ & $4.7 \pm 0.9$ & $6.0 \pm 0.6$ \\
\hline & & III & $35 \pm 1$ & $215 \pm 5$ & $2.5 \pm 0.1$ & $113 \pm 10$ & $125 \pm 10$ & $12.0 \pm 1.0$ & $9.0 \pm 1.0$ \\
\hline \multirow{3}{*}{$33-16$} & \multirow{3}{*}{ 91F9S } & I & $11 \pm 1$ & $42 \pm 3$ & $0.7 \pm 0.1$ & $21 \pm 3$ & $25 \pm 3$ & $1.5 \pm 0.5$ & $3.3 \pm 0.9$ \\
\hline & & II & $25 \pm 4$ & $83 \pm 25$ & $1.5 \pm 0.4$ & $57 \pm 23$ & $73 \pm 29$ & $2.0 \pm 1.0$ & $4.7 \pm 0.9$ \\
\hline & & III & $38 \pm 2$ & $201 \pm 35$ & $2.9 \pm 0.3$ & $131 \pm 30$ & $135 \pm 5$ & $4.0 \pm 1.1$ & $5.0 \pm 1.0$ \\
\hline \multirow{3}{*}{$34-16$} & \multirow{3}{*}{$100 \mathrm{~F}$} & I & $14 \pm 2$ & $59 \pm 2$ & $1.0 \pm 0.1$ & $43 \pm 3$ & $60 \pm 3$ & $4.7 \pm 0.7$ & $5.7 \pm 0.7$ \\
\hline & & II & $23 \pm 2$ & $116 \pm 15$ & $1.9 \pm 0.3$ & $71 \pm 5$ & $83 \pm 7$ & $5.5 \pm 2.2$ & $6.3 \pm 1.3$ \\
\hline & & III & $29 \pm 5$ & $210 \pm 18$ & $2.8 \pm 0.2$ & $179 \pm 17$ & $128 \pm 11$ & $7.3 \pm 3.2$ & $7.7 \pm 2.3$ \\
\hline Tegulde & tskoe forest u & & & & & & & & \\
\hline $45-16$ & $100 \mathrm{~F}$ & I & $3 \pm 1$ & $13 \pm 3$ & $0.4 \pm 0.1$ & - & - & - & - \\
\hline Tomsk z & zoological res & rve & & & & & & & \\
\hline & & I & $8 \pm 3$ & $22 \pm 5$ & $0.4 \pm 0.1$ & $15 \pm 5$ & $28 \pm 3$ & $3.5 \pm 1.0$ & - \\
\hline 60-17 & 94r4P1S1 & II & $22 \pm 2$ & $60 \pm 3$ & $1.0 \pm 0.4$ & $35 \pm 2$ & $42 \pm 8$ & $2.6 \pm 0.7$ & - \\
\hline
\end{tabular}

Legend: I - small (up to $0.59 \mathrm{~m}$ ), II - medium (0.60-1.59), III - large saplings (more than $1.60 \mathrm{~m}$ ); F Siberian fir Abies sibirica Ledeb., P - Siberian pine Pinus sibirica Du Tour, S - Siberian spruce Picea obovata Ledeb., Sp - Scots pine Pinus sylvestris L. 
Table 2. Characteristics of saplings in fir forests damaged by the four-eyed fir bark beetle (Polygraphus proximus Blandf.) on the left bank of the Ob River.

\begin{tabular}{|c|c|c|c|c|c|c|c|c|}
\hline No. SP & $\begin{array}{l}\text { Composition, } \\
\%\end{array}$ & $\begin{array}{l}\text { Size } \\
\text { cate- } \\
\text { gory }\end{array}$ & $\begin{array}{l}\text { Age, } \\
\text { yrs }\end{array}$ & Height, $\mathrm{cm}$ & $\begin{array}{l}\text { Diameter, } \\
\mathrm{cm}\end{array}$ & $\begin{array}{l}\text { Crown } \\
\text { length, } \mathrm{cm}\end{array}$ & $\begin{array}{l}\text { Crown } \\
\text { width, } \mathrm{cm}\end{array}$ & $\begin{array}{l}\text { Growth of } \\
\text { axial shoot, } \\
\text { cm yrs }^{-1}\end{array}$ \\
\hline \multicolumn{9}{|c|}{ Krivosheinskoe forest unit } \\
\hline \multirow{2}{*}{$50-17$} & \multirow{2}{*}{ 89F5P5A1S } & I & $14 \pm 2$ & $36 \pm 5$ & $0.6 \pm 0.1$ & $20 \pm 3$ & $33 \pm 5$ & $2.2 \pm 0.3$ \\
\hline & & II & $27 \pm 3$ & $94 \pm 13$ & $1.4 \pm 0.2$ & $64 \pm 9$ & $78 \pm 8$ & $4.2 \pm 0.9$ \\
\hline \multirow{2}{*}{$51-17$} & \multirow{2}{*}{ 96F2P2S } & I & $11 \pm 1$ & $34 \pm 5$ & $0.6 \pm 0.1$ & $28 \pm 4$ & $29 \pm 4$ & $3.8 \pm 0.7$ \\
\hline & & II & $20 \pm 2$ & $81 \pm 11$ & $1.4 \pm 0.3$ & $64 \pm 10$ & $57 \pm 9$ & $9.4 \pm 1.8$ \\
\hline \multirow{2}{*}{$52-17$} & \multirow{2}{*}{ 87F9A4S } & I & $6 \pm 2$ & $27 \pm 5$ & $0.5 \pm 0.2$ & $16 \pm 4$ & $26 \pm 6$ & $1.7 \pm 0.7$ \\
\hline & & II & $24 \pm 4$ & $96 \pm 14$ & $1.5 \pm 0.2$ & $47 \pm 5$ & $73 \pm 7$ & $4.1 \pm 0.5$ \\
\hline \multicolumn{9}{|c|}{ Poskoevsky zoological reserve } \\
\hline \multirow{3}{*}{$54-17$} & \multirow{3}{*}{ 81F19S } & I & $11 \pm 1$ & $32 \pm 1$ & $0.6 \pm 0.1$ & $17 \pm 1$ & $35 \pm 4$ & $1.8 \pm 0.9$ \\
\hline & & II & $29 \pm 3$ & $102 \pm 17$ & $1.8 \pm 0.2$ & $62 \pm 8$ & $94 \pm 12$ & $3.4 \pm 0.5$ \\
\hline & & III & $31 \pm 2$ & $185 \pm 17$ & $2.4 \pm 0.4$ & $88 \pm 27$ & $100 \pm 10$ & $3.7 \pm 1.2$ \\
\hline \multicolumn{9}{|c|}{ Shegarskoe forest unit } \\
\hline $55-17$ & 92F7P1A & I & $8 \pm 2$ & $26 \pm 4$ & $0.4 \pm 0.1$ & $18 \pm 1$ & $23 \pm 3$ & $4.0 \pm 0.5$ \\
\hline \multicolumn{9}{|c|}{ Bakcharskoe forest unit } \\
\hline \multirow{2}{*}{$57-17$} & \multirow{2}{*}{$98 \mathrm{~F} 2 \mathrm{~A}$} & II & $22 \pm 2$ & $76 \pm 8$ & $1.2 \pm 0.1$ & $39 \pm 6$ & $59 \pm 6$ & $3.1 \pm 0.8$ \\
\hline & & III & $45 \pm 4$ & $179 \pm 7$ & $2.4 \pm 0.1$ & $108 \pm 5$ & $126 \pm 8$ & $5.7 \pm 1.7$ \\
\hline \multirow{2}{*}{$58-17$} & \multirow{2}{*}{ 94F4P1S1A } & I & $13 \pm 1$ & $35 \pm 1$ & $0.5 \pm 0.1$ & $23 \pm 1$ & $26 \pm 1$ & $4.2 \pm 0.2$ \\
\hline & & II & $27 \pm 3$ & $83 \pm 10$ & $1.3 \pm 0.2$ & $61 \pm 10$ & $62 \pm 8$ & $7.0 \pm 1.7$ \\
\hline
\end{tabular}

Legend: I - small (up to $0.59 \mathrm{~m}$ ), II - medium (0.60-1.59), III - large saplings (more than $1.60 \mathrm{~m}$ ); F -

Siberian fir Abies sibirica Ledeb., P - Siberian pine Pinus sibirica Du Tour, S - Siberian spruce Picea obovata Ledeb., A - aspen Populus tremula L.

equalled $71 \pm 9 \%$ (limited to $22-98 \%$ ), without a significant difference (Mann-Whitney test, $p=0.97)$. However, the average number of saplings differed significantly (Mann-Whitney test, $p=0.03$ ), with 7,243 $\pm 1,619$ plants ha-1 on the right bank (limited to 1,233-19,200 plants ha-1) and 2,724 \pm 801 plants ha-1 on the left bank (limited to 260-8,540 plants ha-1).

Most likely, the main reason for such disparities is that the left bank is swampier - in particular, the southern taiga is directly influenced by the Great Vasyugan swamp, which leaves an imprint on the typological structure of the forests. The fir forests of the right bank mainly contain green mosses and small grasses, while on the left bank, sedges are more common.

Analysis of the impact of the stand damage on sapling occurrence showed a weak positive dependence on the right bank (Spearman correlation, $r=-0.33$, $p=0.93)$. In relation to the number of saplings, such a connection could not be revealed (Spearman correlation, $r=-0.08$, $p=0.54)$. These patterns were also confirmed for fir forests on the left bank, with a weak positive correlation (Spearman correlation, $r=-0.28, p=0.65$ ) with occurrence and no significant relationship (Spearman correlation, $r=-0.17, p=0.69$ ) with the number of saplings. However, the correlation coefficients are unreliable, and these connections are not yet confirmed.

Spatially, the NR sites were highly heterogeneous. The scattering index was constantly higher than 1, particularly in mixed stands and when small and medium saplings dominated. This indicates a group placement of the regeneration on the one hand (with an occurrence coefficient of below $65 \%$ ) and variable density with an even occurrence of saplings (above 65\%) on the other. For fir forests of the right 


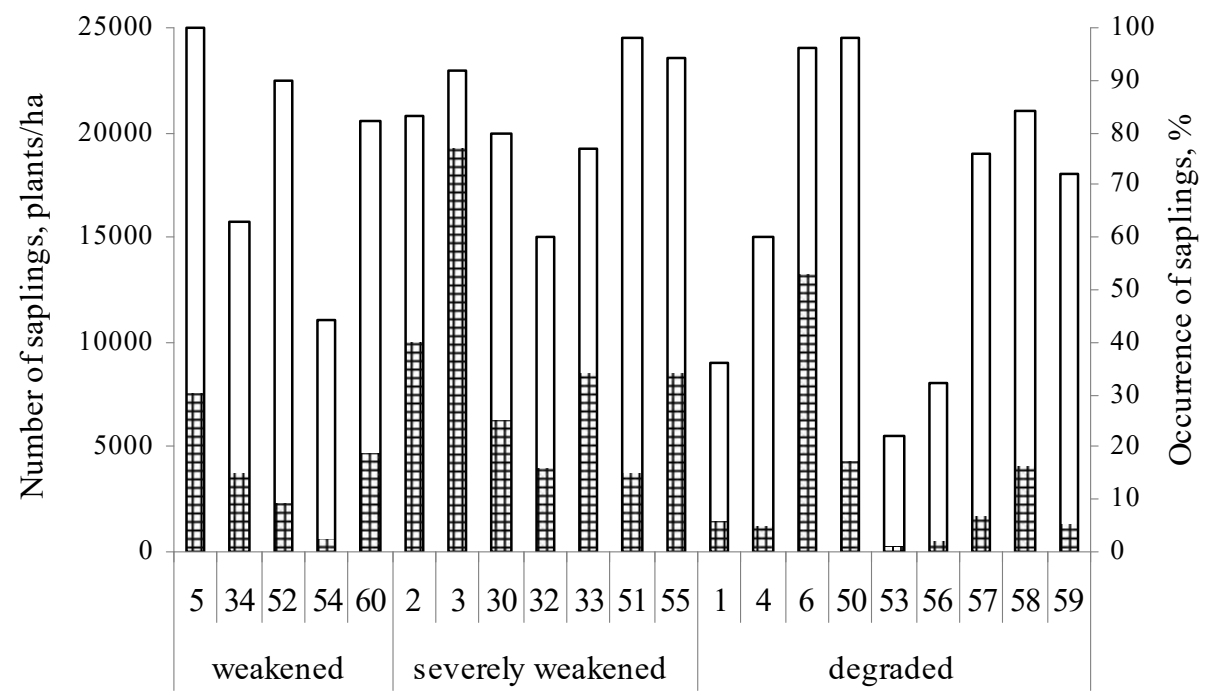

Sample plot no. and Stand health state \# Number

$\square$ Occurrence

Figure 2. Number and occurrence of natural regeneration in fir forests of various degrees of damage on the left and right bank of the Ob River.

bank, the scattering coefficient was $4.9 \pm$ 1.1 (limited to 1.5-12.1), while for the left bank, it was $1.8 \pm 0.4$ (limited to 1.0-4.6). A significant difference (Mann-Whitney test, $p=0.00$ ) was established for this indicator, suggesting that right-bank fir forests have a more grouped placement of saplings. The analysis of the stand damage affecting the scattering coefficient of saplings showed a relationship different from that of the right bank (Spearman correlation, $r=-0.19$, $p=0.47)$ and the left bank (Spearman correlation, $r=+0.22, p=0.82)$.

\section{The direct impact of the four-eyed fir bark} beetle on Siberian fir NR

In $63 \%$ of SPs, sapling mortality was recorded as a result of the impact of the four-eyed fir bark beetle. The variation in this indicator was relatively high: from an insignificant $2-3 \%$ to a very substantial $8-13 \%$. A positive relationship between the amount of dead saplings and the health state category of the fir forest (Spearman correlation, $r=+0.36, p=0.27$ ) was revealed. This link shows how the overall state of the stand leads to a decrease in saplings - a poor state of the adult fir generation leads to a reduction in the feed base of the beetle, so the insect explores a more subtle part of the community (however, this only occurs during mass reproduction). At the same time, the main share of the dead saplings falls on the large category (95\%), and only $5 \%$ on the medium one. This means the beetle attacks firs up to a certain limit, corresponding to the medium-size category or up to $1.6 \mathrm{~m}$. For several biological reasons, small saplings are not conducive to bringing up new generations of bark beetles. Indirectly, this is confirmed by the analysis of the relationship between the number of dead saplings and the number of large saplings (Spearman correlation, $r=+0.92, p=$ 0.01). This means that when in an NR site, large saplings prevail, the death of such saplings should be expected during mass reproduction of the beetle. In this regard, it is necessary to clarify the previously indicated values of sapling deaths of the large category: 10-50\%. This fundamentally 
changes the understanding of the situation and allows taking a fresh look at the transformational role of the four-eyed fir bark beetle in relation to Siberian fir.

\section{Microsite structure of fir forests}

Average microsite structures of the fir forests of the right bank of the Ob River (Figure 3), impacted by the four-eyed fir bark beetle, include microsites of the I order, such as intercrown (40.5\%), undercrown of living trees $(42.6 \%)$, undercrown of dieback $(11.4 \%)$ and undercrown of windbreak and windfall (5.6\%) of the plots. A similar structure was observed for the left bank, where intercrown plots represented $35.9 \%$, the undercrown of living trees represented $42.0 \%$, and the undercrown of dieback represented $22.1 \%$. In the rightbank sites, windbreak and windfall undercrown plots were common, most likely because of the dieback breaking off, noted in the right-bank firs previously invaded by the four-eyed fir bark beetle.

A large percentage of saplings was confined to such microsites of the II order, such as even plots (more than $70 \%$ ), irrespective of the stand disturbance degree (Figure 4). Also, a significant (about 20-35\%) number of saplings were located on pans, and a small amount on stumps and deadwood (less than 10\%).

Regarding microsites of the I order, the total number of saplings did not correspond to the presentation of certain microsites in the fir forests of the right bank. A larger proportionality of this aspect was observed for severely weakened stands, and somewhat less for weakened stands, but the recorded numbers are approximately two times greater for the undercrown plots of windfall and windbreak, which can be attributed to the so-called "gap dynamics" characteristic of unevenaged forests. At the same time, the numbers for intercrown plots were about two times lower and slightly higher for the undercrown plots of living trees (about 10\%).
The most significant difference was observed for degraded stands characterised by low numbers of saplings in intercrown microsites (two times) and high numbers for undercrown plots of living trees (almost two times). This is a clear evidence of the formation of uneven-aged stands; in degraded communities, the preserved areas with the parent stand most fully transmit the features to the emerging saplings and determine the subsequent focal nature of the reforested stand (Pautov, 1992). In contrast to the right-bank fir forests, the left bank of the Ob River is characterised by high numbers of saplings in intercrown plots (average $8 \%$ ), due to the lower numbers of saplings in undercrown microsites of living trees (by 6\%) and dieback (by 3\%).

The dynamics of the occurrence of saplings in microsites are also subject to certain laws. In the right-bank fir forests, most often, the sapling is absent from intercrown plots (39\% of the microsite area), and in other microsites, the indicator is approximately the same, with $7-9 \%$ of the area being occupied by a particular plot. The lack of saplings in intercrown plots can be explained by the undergrowth and grassy vegetation in the more "herbal" forests in the southern taiga and by the predominance of large saplings in the undercrown plots of windfall and windbreak, in addition to its low occurrence in intercrown plots. On the left bank, contrarily, NR is most often absent in undercrown plots of living trees $(28 \%)$ and dieback $(32 \%)$, and least of all in intercrown plots (23\%).

On the right bank, intercrown plots accounted for $20 \%$ of the mortality, undercrown plots living trees for $60 \%$, undercrown plots of dieback for $10 \%$ and undercrown plots of windfall or windbreak for $5 \%$. This is probably due to the fact that during mass reproduction, the beetles attacking mature trees find it difficult to settle and thus switch to nearby large saplings. On the left bank, the dynamics were different: $40 \%$ of the dead saplings were in the intercrown and undercrown plots of 


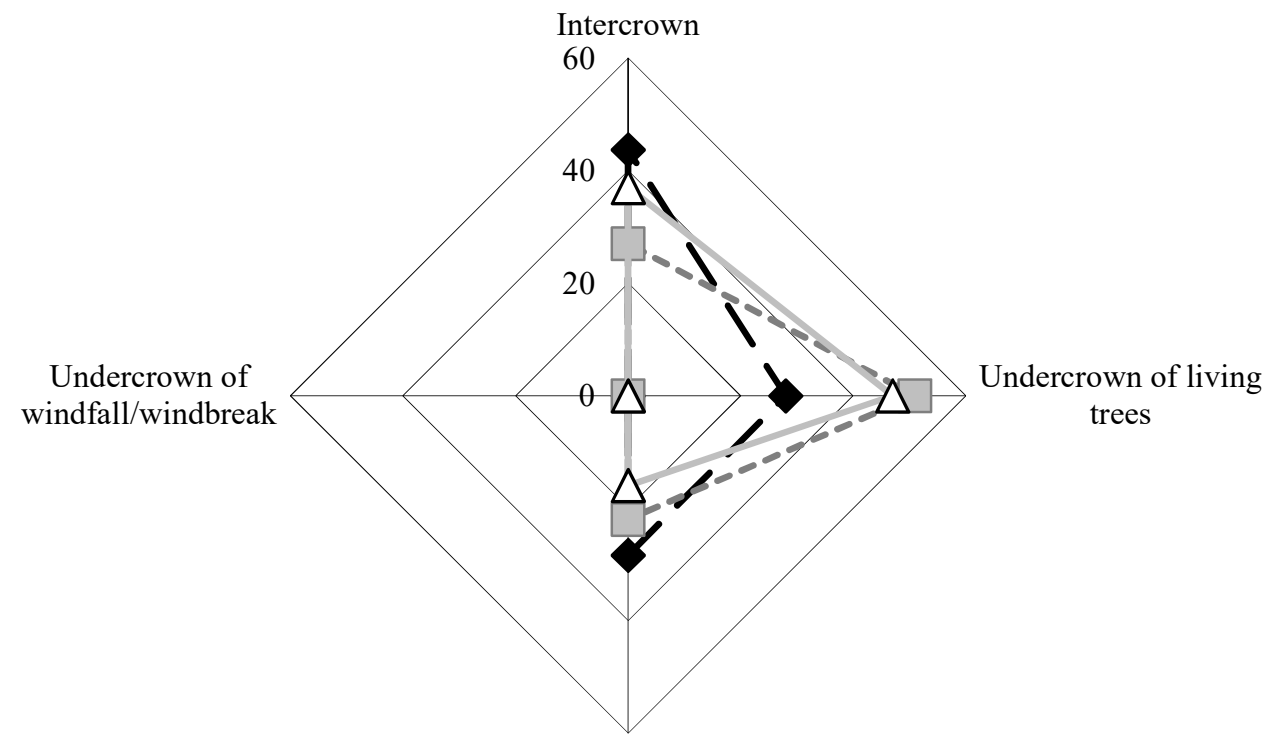

Undercrown of dieback

Stand health state

$\rightarrow-$ Degraded $-\square-$ Severely weakened $\Delta$ Weakened

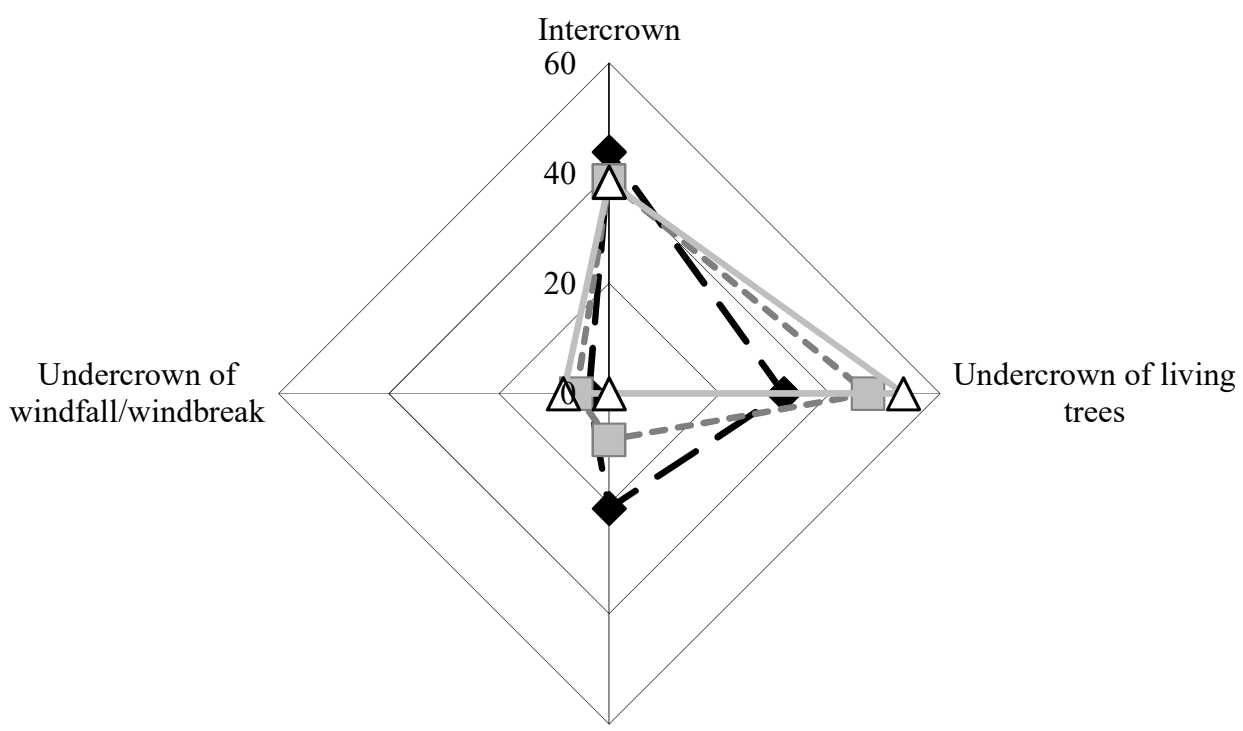

Undercrown of dieback

Stand health state

$\rightarrow$ - Degraded $-\square-$ - Severely weakened $\Delta$ - Weakened

Figure 3. Structure of microsites of fir forests damaged by the four-eyed fir bark beetle the left (top) and the right (bottom) banks of the $0 \mathrm{~b}$ River. 


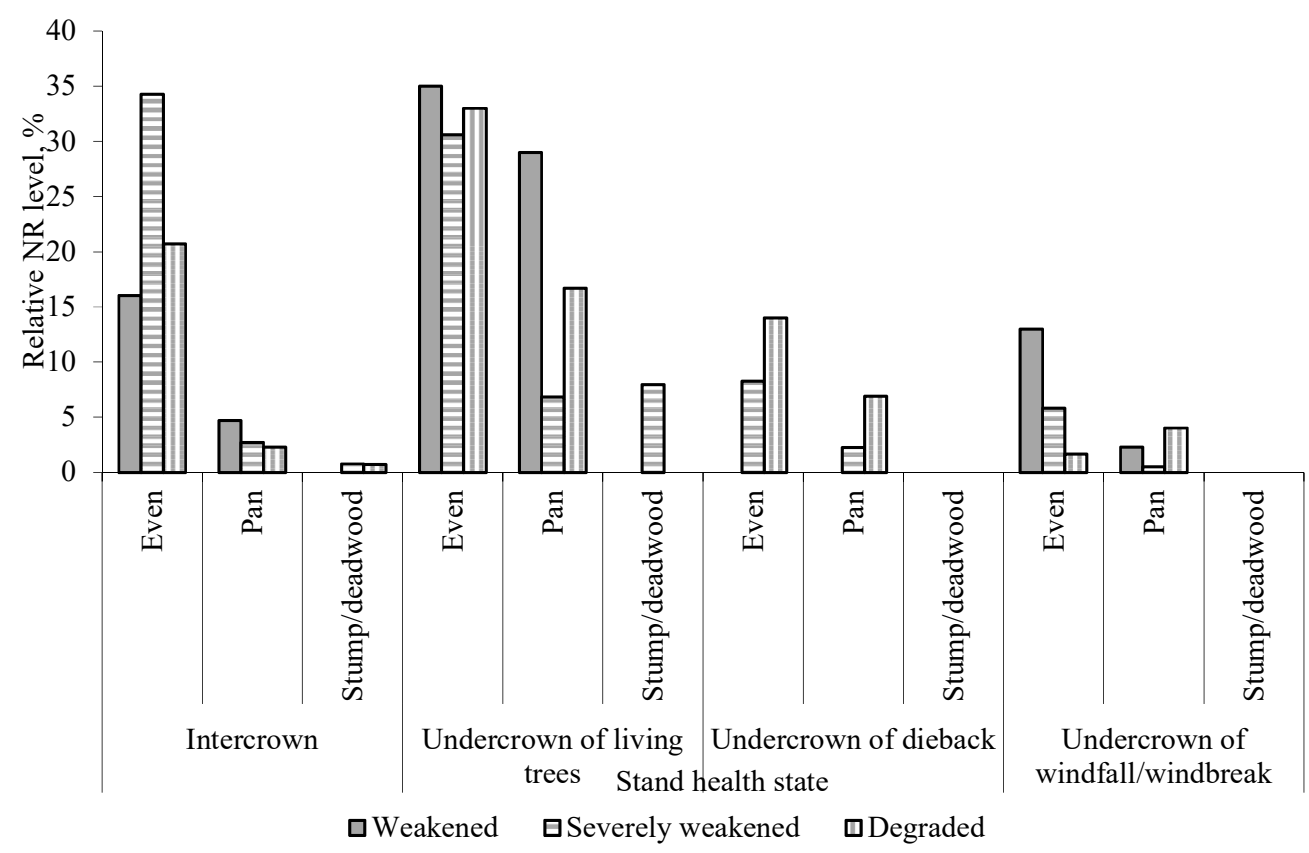

Figure 4. Distribution of fir forests natural regeneration (NR) in various types of microsites.

living trees, and the remaining $20 \%$ were in the undercrown plots of dieback. It should be added that sapling mortality caused by the beetle in these fir forests is not marked.

For comparative analysis, the data on the dead saplings should be considered as a result of the natural growth and development of forest communities. The background level of tree mortality is an indicator of succession dynamics and of the competitive tension for the resources of power as with the parent canopy and other vegetation layers. Sapling dieback of natural origin was observed in all the surveyed stands. Yet, unlike the dieback caused by the beetle, the share of medium saplings in the right-bank fir forests was already $40 \%$, with large saplings accounting for $60 \%$. On the left bank, due to the slightly different height structure of NR saplings and more stringent conditions of competition with grasses (sedge), the dynamics of decline are more aligned: small saplings account for $35 \%$, medium ones for $27 \%$ and large ones for $38 \%$.

\section{Discussion}

Based on the identified features of the four-eyed fir bark beetle distribution in the Tomsk region, it is possible to make a number of important conclusions for forestry practice, namely: the upper border of the invader distribution practically coincides with the northern border of the southern taiga. It should be noted here that one of the indicators of the border between the middle and southern taiga is the occurrence of fir stands. It is well known that forests dominated by Siberian fir practically do not occur in the middle taiga, where fir only participates in the composition of multispecies dark-coniferous taiga. Taking into account the above, the author distinguishes the potential upper limit of the four-eyed fir bark beetle distribution on the left bank of the Ob River, where its appearance can be expected in the near future. This includes the southern parts of Kargasoksky (6) and Parabelsky districts (11). 
Tree species with a wide range, covering different forest areas and environmental conditions, are more resistant to complete degradation. For example, in dark-coniferous forests of the Appalachian mountains (Stehn et al., 2013), balsam woolly adelgid (Adelges piceae Ratz.) damages the forest to a height of $1,750 \mathrm{~m}$ above the sea level, but beyond this, Fraser fir (Abies fraseri (Pursh) Poir.) retains forestforming significance.

The most important element of a forest ecosystem is a viable regeneration to provide a continuous stream of generations. The impact of invasive organisms can either lead to the complete destruction of young generations or significantly slow down processes of their growth and development to such an extent that there is a change in dominant tree species (McLaren et al., 2009). Our data indicate a concrete, but not extreme influence of the four-eyed fir bark beetle on regeneration processes. The number and state of fir regeneration in most of the stands subjected to the invasion of the four-eyed fir bark beetle are satisfactory, and in the long term, the natural restoration of fir forests is guaranteed.

The number of under-canopy generations of indigenous species is important, especially in stands damaged to a large extent. Some authors (Stehn et al., 2013) have shown that the local density of species that have undergone invasion is highly variable. This, in turn, is an important factor in predicting the future dynamics of disturbed ecosystems. For example, according to Fajvan \& Wood (1996), there was an increase in the number of oak saplings (species exposed to invasion) only on the southern slopes in the Appalachian Plateau.

The impact of an invasive organism can often lead to an increase in the regenerative functions of the damaged ecosystems, for example, when gaps formed in the canopy as a result of the death of the eastern hemlock (Tsuga canadensis (L.) Carrière) trees, but the forests became actively populated by undergrowth (Small et al., 2005). At the same time, both in the above-mentioned example and according to a previous study (Jenkins, 2003), in forests dominated by Fraser fir, a decrease in the number of naturally regenerated trees was observed. Strengthening the regenerative process is due to accompanying species, which, in our case, was not noted. However, it can be concluded that even these features of regeneration make it possible to continue the domination of the main tree species in the long term, eastern hemlock (Weckel et al., 2006) and Fraser fir (Stehn et al., 2013), respectively.

A similar situation has been observed in fir forests or forests with a significant participation of fir in the pre-Urals, where, according to some authors (Lugovaya et al., 2013), the total share of undercrown plots ranges from 50 to $70 \%$, while intercrown plots account for 20 to $40 \%$ or more. According to other authors (Zaprudina, 2010), the largest area is occupied by intercrown (46\%) and undercrown plots (47\%), while the share of other types of microsites is $5 \%$. In the case of stand damage by insects, the horizontal structure of the canopy changes (Gandhi \& Herms, 2010). For example, interesting effects have been revealed in the case of the emerald ash borer Agrilus planipennis Fairmaire (Knight et al., 2013); areas with a lower density of ash Fraxinus spp. trees were more susceptible to damage.

The transformation of microsites of the I order is clearly manifested depending on the damage to the community. In particular, with increasing damage to fir forests on the right bank, the proportion of undercrown plots of living trees among the weakened, severely weakened and degraded stands (53-47-32\%, respectively) naturally decreased. A similar situation was observed for the left-bank fir forests (28-51-47\%, respectively). This leads to an opposite change in the share of the undercrown of dieback (8-15-25\%). There were no differences in the proportions of intercrown and former undercrown windbreaks 
and windfalls which were transformed as a result of abiotic and biotic causes. In stands damaged by the beetle, a further transformation of the microsite structure is predicted, namely, the undercrown plots of dieback will decrease, while the undercrown plots of windbreak will increase. This is because most often, fir breaks off at a certain height without the formation of stumps suitable for sapling settling. In turn, the ratio of microsites of the II order will change, namely, the area occupied by large wood residues (broken parts of trunks) will increase. However, the substrate will be suitable for the colonisation by woody plants only in the later stages of decomposition (Aleinikov \& Bovkunov, 2011); in the case of fir, according to the authors' observations, this period lasts an average of about 15-25 years. This forecast is more reliable for degraded stands, where there is no feed base for the four-eyed fir bark beetle. In weakened stands, the bark beetle can potentially multiply, with the probability of transformation processes happening differently.

Similar patterns have been observed previously. In particular, it was noted that the number of small saplings was higher under the crown of living trees than in areas occupied by dead stands (Smith \& Nicholas, 2000), which might be due to the strong development of underground vegetation, including the grass cover.

\section{Conclusions}

Both somewhat weakened and degraded fir stands have the potential to naturally regenerate, mainly by Siberian fir. No connection between the number of saplings and the extent of damage to communities was identified, but the supply of regenerated fir forests on the right bank of the $\mathrm{Ob}$ River stands out as it was almost three times higher when compared to the left bank $\left(7,243 \pm 1,619\right.$ plants ha $^{-1}$ vs 2,724 \pm 801 plants ha-1). These forests are also char- acterised by a significantly higher grouping of saplings.

Saplings death as a result of the impact of the four-eyed fir bark beetle was recorded. In the case of mass reproduction, the invader mainly attacks large saplings, of which a significant portion dies.

The transformation of the microsite structure of fir forests is manifested in the appearance of new types of microsites of the I order in disturbed forests - of undercrown plots of dieback with inherent features of light and temperature conditions. Short- and medium-term forecasts are reduced to the continuation of this process with an increase in deadwood (due to windbreak), which acts as a biogenic substrate that can be used for reproduction at the later stages of decomposition. The greater part (more than $70 \%$ ) of saplings was confined to even plots, mainly on pans.

Acknowledgements. The reported research was funded by the Russian Foundation for Basic Research and the government of the Tomsk region, grant № 16-44-700782. The author would like to thank Svetlana A. Krivets, Elvina M. Bisirova, Ivan A. Kerchev and Natalie A. Chernova (Institute of Monitoring of Climatic and Ecological Systems, Tomsk, Russia) for gathering data.

\section{References}

Aitken, S.N., Yeaman, S., Holliday, J.A., Wang, T., Curtis-McLane, S. 2008. Adaptation, migration or extirpation: climate change outcomes for tree populations. - Evolutionary Applications, $1(1), 95-111$.

Aleinikov, A.A., Bovkunov, A.D. 2011. Micromosaic organization of large tall grass and fir-spruce forests of the PechoraIlych nature reserve. (Микромозаичная организация крупнопапоротниковых и высокотравных пихто-ельников ПечороИлычного заповедника). - Bulletin of Penza University named after V.G. Belinsky, 25, 3846. (In Russian). 
Allen, C.D., Macalady, A.K., Chenchouni, H., Bachelet, D., McDowelle, N., Vennetier, M., Kitzberger, T., Rigling, A., Breshears, D.D., (Ted) Hogg, E.H., Gonzalez, P., Fensham, R., Zhang, Z., Castro, J., Demidova, N., Lim, J.-H., Allard, J., Running, S.W., Semerci, A., Cobb, N. 2010. A global overview of drought and heat-induced tree mortality reveals emerging climate change risks for forests. - Forest Ecology and Management, 259(4), 660-684.

Anderegg, L.D.L, Anderegg, W.R.L., Berry, J.A. 2013. Not all droughts are created equal: translating meteorological drought into woody plant mortality. - Tree Physiology, 33(7), 701-712.

Born, W., Rauschmayer, F., Bräuer, I. 2005. Economic evaluation of biological invasions a survey. - Ecological Economics, 55(3), 321336.

Fajvan, M.A., Wood, J.M. 1996. Stand structure and development after gypsy moth defoliation in the Appalachian plateau. - Forest Ecology and Management, 89(1-3), 79-88.

Gandhi, K.J.K, Herms, D.A. 2010. Direct and indirect effects of alien insect herbivores on ecological processes and interactions in forests of eastern North America. - Biological Invasions, 12, 389-405.

Jenkins, M.A. 2003. Impact of the balsam woolly adelgid (Adelges piceae Ratz.) on an Abies fraseri (Pursh) Poir. dominated stand near the summit of Mount LeConte, Tennessee. - Castanea, 68(2), 109-118.

Kenis, M., Auger-Rozenberg, M.-A., Roques, A., Timms, L., Péré, C., Cock, M.J.W., Settele, J., Augustin, S., Lopez-Vaamonde, C. 2009. Ecological effects of invasive alien insects. Biological Invasions, 11(1), 21-45.

Kharuk, V.I., Im, S.T., Oskorbin, P.A., Petrov, I.A., Ranson, K.J. 2013. Siberian pine decline and mortality in Southern Siberian mountains. Forest Ecology and Management, 310, 312-320.

Knight, K.S., Brown J.P., Long R.P. 2013. Factors affecting the survival of ash (Fraxinus spp.) trees infested by emerald ash borer (Agrilus planipennis). - Biological Invasions, 15(2), 371383.

Krivets, S.A., Baranchikov, Yu.N. 2015. Four-eyed Fir Bark Beetle in Siberian Forests (Distribution, Biology, Ecology, Detection and Survey of Damaged Stands). (Уссурийский полиграф в лесах Сибири (распространение, биология, экология, выявление и обследование поврежденных насаждений). TomskKrasnoyarsk, Umium. 48pp. (In Russian).

Krivets, S.A., Bisirova, E.M., Kerchev, I.A., Pats, E.N., Chernova, N.A. 2015. Transformation of taiga ecosystems in the Western Siberian invasion focus of four-eyed fir bark beetle Polygraphus proximus Blandf. (Coleoptera: Curculionidae, Scolytinae). - Russian Journal of Biological Invasions, 6(2), 94-1 08.
Logan, J.A., Régnière, J., Powell, J.A. 2003. Assessing the impacts of global warming on forest pest dynamics. - Frontiers in Ecology and the Environment, 1, 130-137.

Lugovaya, D.L., Smirnova, O.V., Zaprudina, M.V., Aleynikov, A.A., Smirnov, V.E. 2013. Micromosaic structure and phytomass of ground vegetation in main types of dark conifer forests in the Pechora-Ilych state nature reserve. (Микромозаичная организация и фитомасса напочвенного покрова в основных типах темнохвойных лесов Печоро-Илычского заповедника). - Russian Journal of Ecology, 4, 1-8. (In Russian).

Makhatkov, I.D. 1991. Polyvariant Ontogenesis of the Siberian Fir. (Поливариантность онтогенеза пихты сибирской). - Bulletin of Moscow Society of Naturalists, Biological series, 96(4), 79-88. (In Russian).

Martínez-Vilalta, J., Lloret, F., Breshears, D.D. 2012. Drought-induced forest decline: causes, scope and implications. - Biology Letters, 8(5), 689-691.

McLaren, B., Hermanutz, L., Gosse, J., Collet, B., Kasimos, C. 2009. Broadleaf competition interferes with balsam fir regeneration following experimental removal of moose. - Forest Ecology and Management, 257(5), 1395-1404.

Pautov, Yu.A. 1992. Man-made Logging Structure as the Basis of Reforestation Technology. Scientific Advice for the National Economy. (Техногенная структура вырубок основа технологии лесовосстановления). Syktyvkar, Ural branch of USSR. 20 pp. (In Russian).

Pobedinskiy, A.V. 1966. Investigation of Reforestation Processes. (Изучение лесовосстановительных процессов). Moscow, Nauka. 64 pp. (In Russian).

Poland, T.M., McCullough, D.G. 2006. Emerald ash borer: invasion of the urban forest and the threat to North America's ash resource. Journal of Forestry, 104(3), 118-124.

Raffa, K.F., Aukema, B.H., Bentz, B.J., Carroll, A.L., Hicke, J.A., Turner, M.G., Romme, W.H. 2008. Cross-scale drivers of natural disturbances prone to anthropogenic amplification: the dynamics of bark beetle eruptions. BioScience, 58, 501-517.

Small, M.J., Small, C.J., Dreyer, G.D. 2005. Changes in a hemlock-dominated forest following woolly adelgid infestation in southern New England. - Journal of the Torrey Botanical Society, 132(3), 458-470.

Smith, G.F., Nicholas, N.S. 2000. Size- and ageclass distributions of Fraser fir following balsam woolly adelgid infestation. - Canadian Journal of Forest Research, 30(6), 948-957.

Stehn, S.E., Jenkins, M.A., Webster, C.R., Jose, S. 2013. Regeneration responses to exogenous disturbance gradients in southern Appalachian Picea-Abies forests. - Forest Ecology and Management, 289, 98-105. 
Straw, N.A., Williams, D.T., Kulinich, O., Gninenko, Yu.I. 2013. Distribution, impact and rate of spread of emerald ash borer Agrilus planipennis (Coleoptera: Buprestidae) in the Moscow region of Russia. - Forestry, 86, 515522.

Svalov, S.N.1985. Application of statistical methods in forestry. (Применение статистических методов в лесоводстве). - Forest Science and Forestry, 4, 1-164. (In Russian).

Uspensky, E.I. 1987. The forest regeneration process under the canopy of smallleaved forests of the middle Volga region. (Лесовозобновительный процесс под пологом мелколиственных лесов Среднего Поволжья). - Forestry Journal, 3, 116-118. (In Russian).

Weckel, M., Tirpak, J.M., Nagy, C., Christie, R. 2006. Structural and compositional change in an old-growth eastern hemlock Tsuga canadensis forest, 1965-2004. - Forest Ecology and Management, 231(1-3), 114-118.

Worrall, J.J., Marchetti, S.B., Egeland, L., Maska, R.A., Eager, T., Howell, B. 2010. Effects and etiology of sudden aspen decline in southwestern Colorado, USA. - Forest Ecology and Management, 260(5), 638-648.
Yousefpour, R., Hanewinkel, M., Le Moguédec, G. 2010. Evaluating the suitability of management strategies of pure Norway spruce forests in the Black Forest Area of Southwest Germany for adaptation to or mitigation of climate change. - Environmental Management, 45(2), 387-402.

Zaprudina, M.V. 2010. Phytomass of grass-shrub and moss layers of tall coniferous forests of the Pechora-Ilych nature reserve. (Фитомасса травяно-кустарничкового и мохового ярусов темнохвойных высокотравных лесов Печоро-Илычского заповедника). Proceedings of the Samara scientific center, 1(3), 876-879. (In Russian).

Zaugolnova, L.B., Braslavskaya, T.J. 2010. Methodological approaches to environmental assessment of the forest canopy cover in a small river basin. (Методические подходы к экологической оценке лесного покрова в бассейне малой реки). Moscow, Association of scientific publications. 383 pp. (In Russian). 